OLIVEIRA, RSV; SALOMÃO, LC; MORGADO, HS; SOUSA, CM; OLIVEIRA, HFE. 2020. Growth and production of basil under different luminosity and water replacement levels. Horticultura Brasileira 38: 324-328. DOI - http://dx.doi.org/10.1590/S0102-053620200314

\title{
Growth and production of basil under different luminosity and water replacement levels
}

\author{
Rívia de SV Oliveira $^{1} \mathbb{D}$; Leandro C Salomão ${ }^{2} \mathbb{D}$; Hélber S Morgado ${ }^{1} \mathbb{D}$; Cleiton Mateus Sousa ${ }^{1} \mathbb{D}$; Henrique \\ FE de Oliveira ${ }^{1} \mathbb{D}$
}

1'Instituto Federal Goiano (IFGoiano), Ceres-GO, Brasil; riviasv@gmail.com; helber.morgado@ifgoiano.edu.br; cleiton.sousa@ifgoiano. edu.br; henrique.fonseca@ifgoiano.edu.br; ${ }^{2}$ Instituto Federal Goiano (IFGoiano), Urutaí-GO, Brasil; leandro.salomao@ifgoiano.edu.br

\begin{abstract}
Basil is used as spice and for medicinal purposes. Its growth is influenced by environmental factors, mainly soil moisture and air temperature. Thus, this study was installed to evaluate growth and production of basil under different levels of luminosity and water replacement. The experimental design was completely randomized, with six replicates, arranged in split plot scheme, with three luminosity levels in the plots (full sun, $50 \%$ and $70 \%$ shading) and four water replacement levels in the subplots $(25,50,75$ and $100 \%$ ETc). We evaluated plant height, stalk diameter, number of leaves and branches, root system volume, the largest root length, fresh and dry mass of roots and leaves. Data were submitted to variance analysis to observe significant differences between treatments and interactions. Luminosity effects were evaluated using Tukey test $(p \leq 0.05 \%)$ and the effects of water regime, with the aid of regression analysis. According to data, $50 \%$ shading and $100 \%$ water replacement, lost through crop evapotranspiration, resulted in higher values of plant height, stalk diameter, branch growth, fresh and dry mass of leaves, and number of leaves. Full sun environment and $100 \%$ water replacement provided an increase in root dry mass and volume.
\end{abstract}

Keywords: Ocimum basilicum, shading, water deficit.

\section{RESUMO}

Crescimento e produção de manjericão em diferentes níveis de luminosidade e reposição hídrica

O manjericão tem utilidade condimentar e medicinal. Seu crescimento é influenciado por fatores ambientais, principalmente pela umidade do solo e temperatura do ar. O objetivo desse trabalho foi avaliar o crescimento e a produção de manjericão sob diferentes níveis de luminosidade e reposição hídrica. Adotou-se o delineamento inteiramente casualizado em esquema de parcelas subdivididas, com três luminosidades nas parcelas (pleno sol e sombreamentos de 50 e 70\%), quatro reposições hídricas nas subparcelas $(25,50,75$ e $100 \%$ ETc) e seis repetições. As variáveis analisadas foram altura da planta, diâmetro do caule, número de folhas e ramos, volume do sistema radicular, comprimento da maior raiz, massa fresca e seca de raízes e folhas. Os dados foram submetidos à análise de variância para detecção de diferenças significativas entre os tratamentos e suas interações. Os efeitos da luminosidade foram avaliados com auxílio do teste Tukey $(\mathrm{p} \leq 0,05)$ e os efeitos dos regimes hídricos, com auxílio de análise de regressão. Os resultados demonstraram que o sombreamento de $50 \%$ e a reposição hídrica de $100 \%$ da evapotranspiração da cultura proporcionaram maiores valores de altura de plantas, de diâmetro de caule, de crescimento de ramos, de massa fresca e massa seca de folhas, e do número de folhas. O ambiente a pleno sol e a reposição hídrica com $100 \%$ da evapotranspiração da cultura favoreceram o aumento da massa seca de raízes e do volume radicular.

Palavras-chave: Ocimum basilicum, sombreamento, déficit hídrico.

Received on November 15, 2019; accepted on June 8, 2020

$\mathrm{B}$ asil is a sub-shrub native to tropical Asia, introduced in Brazil by Italian immigrants. This plant is cultivated in almost all regions of Brazil, mainly by rural producers, in order to be commercialized as condiment and medicinal plant (Marques et al., 2015).

The appropriate botanical nomenclature of Ocimum species belonging to Lamiaceae family, in which basil is included, is of great interest to science. Over 60 species and forms have been recorded, botanical identity of basil cited in some studies is questionable, though. The difficulty in classifying over 60 varieties of Ocimum basilicum is probably due to the cross-pollination, which favors hybridizations and results in a great number of sub species, varieties and forms (Blank et al., 2004). Nevertheless, few investments and studies are destined for this species cultivation (Pereira \& Moreira, 2011).

Plant growth may reflect the ability of species to adapt to the radiation conditions of the environment in which they develop (Almeida et al., 2005). Phytochromes are responsible for identifying and receiving light signals, transforming them into internal responses. These pigments are able to recognize different information related to light, including intensity, wavelength and duration (Han et al., 2007). Light is necessary for photosynthesis, since light is essential to convert luminosity into 
chemical energy (Vieira et al., 2010).

According to Taiz et al. (2017), light influences metabolism and plant developing. In addition to photosynthesis, radiation interferes with germination processes, cotyledon expansion, leaf formation, stem and root growth, flowering, among other morphological responses. These processes are complex and occur due to interaction among several photoreceptors.

Some of the effects observed in plants under water deficit are stomatal closure, inhibition of photosynthetic activity, reduction in cellular and metabolic activities, reduction in cell and leaf expansion, change in carbon partition, reduction in the relationship between root biomass and shoot, leaf abscission, destabilization of membranes and proteins and, finally, cell death (Taiz \& Zeiger, 2013; Taiz et al., 2017).

Hormonal dysfunction, mainly linked to the increased concentration of ethylene in leaves, induces chlorophyll loss and senescence (Taiz et al., 2017).

Since basil leaves are supposed to be eaten in natura, they should be very attractive for commercialization and show high biomass yield (Abreu et al., 2013).

This study was installed to evaluate the development and production of basil under different luminosity levels and water replacements.

\section{MATERIAL AND METHODS}

The research was carried out from May to July 2018, at Instituto Federal Goiano, Campus Ceres (15'20'55"S, 4936'03'W, $578 \mathrm{~m}$ altitude), Rural Zone, Ceres-GO. According to KöppenGeiger, the local climate is Aw - tropical, dry winter (Cardoso \& Marcuzzo, 2014).

Basil seedlings, cultivar Roxo Dark Opal were produced in 128 cells expanded polystyrene trays, filled with the commercial substrate Tropstrato $\mathrm{HA}$ and kept in a nursery during 30 days. Then, the plants were taken to 12-L plastic pots containing substrate composed of ravine soil, bovine manure and sand, in a ratio of $3: 1: 1$. This substrate showed the following physicochemical characteristics: sand =
$589 \mathrm{~g} \mathrm{~kg}^{-1} ;$ silt $=76 \mathrm{~g} \mathrm{~kg}^{-1}$; clay $=335 \mathrm{~g}$ $\mathrm{kg}^{-1} ; \mathrm{pH}$ (in water $)=6.4$; organic matter $=23.2\left(\mathrm{~g} \mathrm{dm}^{-3}\right) ; \mathrm{Ca}=3.2\left(\mathrm{cmolc} \mathrm{dm}^{-3}\right)$; $\mathrm{Mg}=4.5\left(\mathrm{cmolc} \mathrm{dm}^{-3}\right) ; \mathrm{Al}=0.0(\mathrm{cmolc}$ $\left.\mathrm{dm}^{-3}\right) ; \mathrm{H}+\mathrm{Al}=2.0\left(\mathrm{cmolc} \mathrm{dm}^{-3}\right) ; \mathrm{K}=2.5$ $\left(\mathrm{cmolc} \mathrm{dm}^{-3}\right) ; \mathrm{T}=12.3\left(\mathrm{cmolc} \mathrm{dm}^{-3}\right) ; \mathrm{K}$ $=996.0\left(\mathrm{mg} \mathrm{dm}^{-3}\right) ; \mathrm{P}=173.0\left(\mathrm{mg} \mathrm{dm}^{-3}\right)$; $\mathrm{V}=83.12(\%)$.

The experimental design was completely randomized. Plant height $(\mathrm{cm})$, stalk diameter $(\mathrm{mm})$ and number of leaves and branches were evaluated every 15 days. A split-split plot scheme was adopted to perform statistical analysis of data, with five evaluations $(15,30,45,60$ and 75 days) in plots, three environments (full sun, 50 and $70 \%$ shading), in the subplots and four water replacements according to crop evapotranspiration $(25,50,75$ and $100 \%$ ETc) in the subplots and six replicates.

Root system volume, the largest root length, fresh and dry mass of roots and leaves were evaluated at 75 days after the beginning of the research. For these variables, the authors adopted the statistical analysis of data, $3 \times 4$ factorial scheme, being three environments, four water replacements according to the crop evapotranspiration and six replicates, totalizing 72 plants.

In transplant, substrate moisture was increased to the pot capacity (CV) based on the methodology used by Casaroli \& Van Lier (2008). The substrate was kept in this moisture level during eight days and, 9 days after transplant (DAT), we started to apply water replacement treatments, according to Etc (equation 1) measured in each environment.

$$
\mathrm{ETc}=\mathrm{ETo} \times \mathrm{kc}
$$

where, $\mathrm{ETc}=$ crop evapotranspiration $\left(\mathrm{mm} \mathrm{day}{ }^{-1}\right) ; \quad$ ETo $=$ reference evapotranspiration $\left(\mathrm{mm} \mathrm{day}^{-1}\right)$ and $\mathrm{kc}=$ crop coefficient (dimensionless).

ETo was obtained from daily reading in an evaporimetric mini tank installed in the three evaluated environments, using the coefficient of the tank $(\mathrm{kp})=$ 1, according to Salomão (2012) recommendation. For phases I, II, III and IV, the authors adopted respectively kc $0.23 ; 0.27 ; 0.38$ and 1.02 (Marques et al., 2015).

Water replacement was carried out using a localized irrigation system, button-type drippers and selfcompensating flow, at $2.0 \mathrm{~L} \mathrm{~h}^{-1}$ flow and $2 \mathrm{kgf} \mathrm{cm}^{-2}$ pressure.

Obtained data were submitted to variance analysis and, when significant differences, considering interaction between treatments, were noticed, luminosity effects were evaluated with the aid of Tukey test $(p \leq 0.05)$ and effects of water regime, using regression analysis.

\section{RESULTS AND DISCUSSION}

Under full sun, temperatures ranged from 9.8 to $40.0^{\circ} \mathrm{C}$; humidity, from 10 to $99 \%$; and evapotranspiration from 0 to $7 \mathrm{~mm}$. In $50 \%$ shading experiment, temperatures ranged from 9.8 to $37.6^{\circ} \mathrm{C}$; humidity was from 10 to $99 \%$ and evapotranspiration from 0 to $5 \mathrm{~mm}$. In $70 \%$ shading experiment, temperature ranged from 10.1 to $36.5^{\circ} \mathrm{C}$; humidity ranged from 10 to $99 \%$ and evapotranspiration from 0 to $5 \mathrm{~mm}$.

Higher temperatures and radiation under full sun, resulted in greater evapotranspiration, especially in plants kept without water deficit, due to greater water flow and consequently more active energy balance in this environment.

Low luminosity and high temperatures are associated with an increase in endogenous level of gibberellins, which influences directly on plant growth. Oh \& Kim (2014) verified that low light intensity and higher temperatures potentiated the effect of gibberellic acid on the petiole elongation of Cyclamen persicum.

Plant height, stalk diameter and number of branches per plant were influenced by interactions between plant age and the crop environment, between plant age and water replacement, and between the crop environment and water replacement.

Over time, plants grown under shading conditions tended to be higher than plants grown under full sun. In the relationship between plant age and water replacement, the authors noticed an increase in height in plants at all ages, however, under water deficit, shorter height was noticed in relation to $100 \%$ water replacement. Reduction in water 
Table 1. Averages of results found for destructive variables evaluated at 75 days after basil seeding transplant. Ceres, IF Goiano, 2018.

\begin{tabular}{lccccc}
\hline Environment & FLW & DLW & DRW & RSV & RL \\
\hline Full sun & $51.19 \mathrm{a}$ & $8.09 \mathrm{a}$ & $0.58 \mathrm{a}$ & $3.50 \mathrm{a}$ & $15.65 \mathrm{~b}$ \\
$50 \%$ shading & $50.42 \mathrm{a}$ & $7.78 \mathrm{a}$ & $0.47 \mathrm{~b}$ & $3.00 \mathrm{ab}$ & $20.97 \mathrm{a}$ \\
$70 \%$ shading & $44.27 \mathrm{~b}$ & $6.78 \mathrm{~b}$ & $0.40 \mathrm{c}$ & $2.79 \mathrm{~b}$ & $18.75 \mathrm{a}$ \\
\hline
\end{tabular}

$\mathrm{FLW}=$ leaf fresh mass (g/plant); DLW= leaf dry mass $(\mathrm{g} / \mathrm{plant}) ; \mathrm{DRW}=$ root dry mass $(\mathrm{g} /$ plant); RSV= root system volume $\left(\mathrm{cm}^{3} /\right.$ plant $) ; \mathrm{RL}=$ root length $(\mathrm{cm})$.

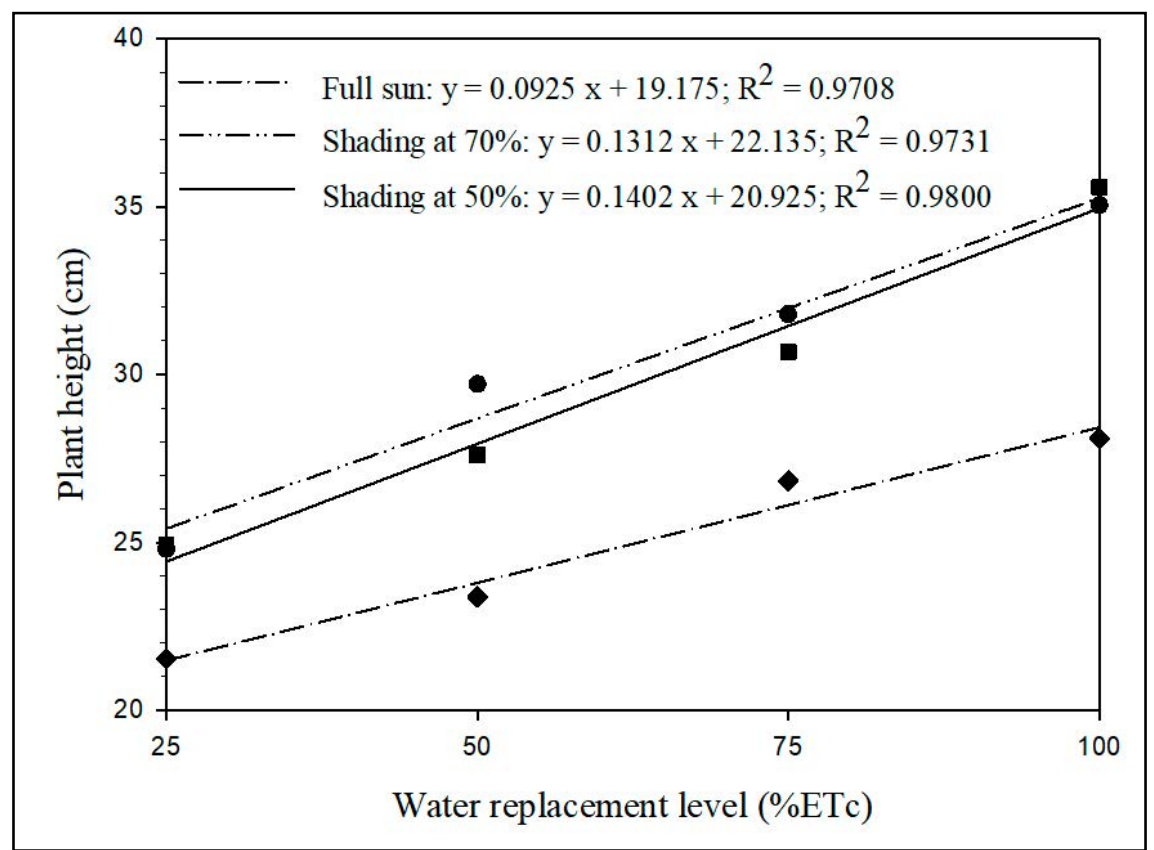

Figure 1. Height of basil plants grown in three environments and four water replacement levels. Ceres, IF Goiano, 2018.

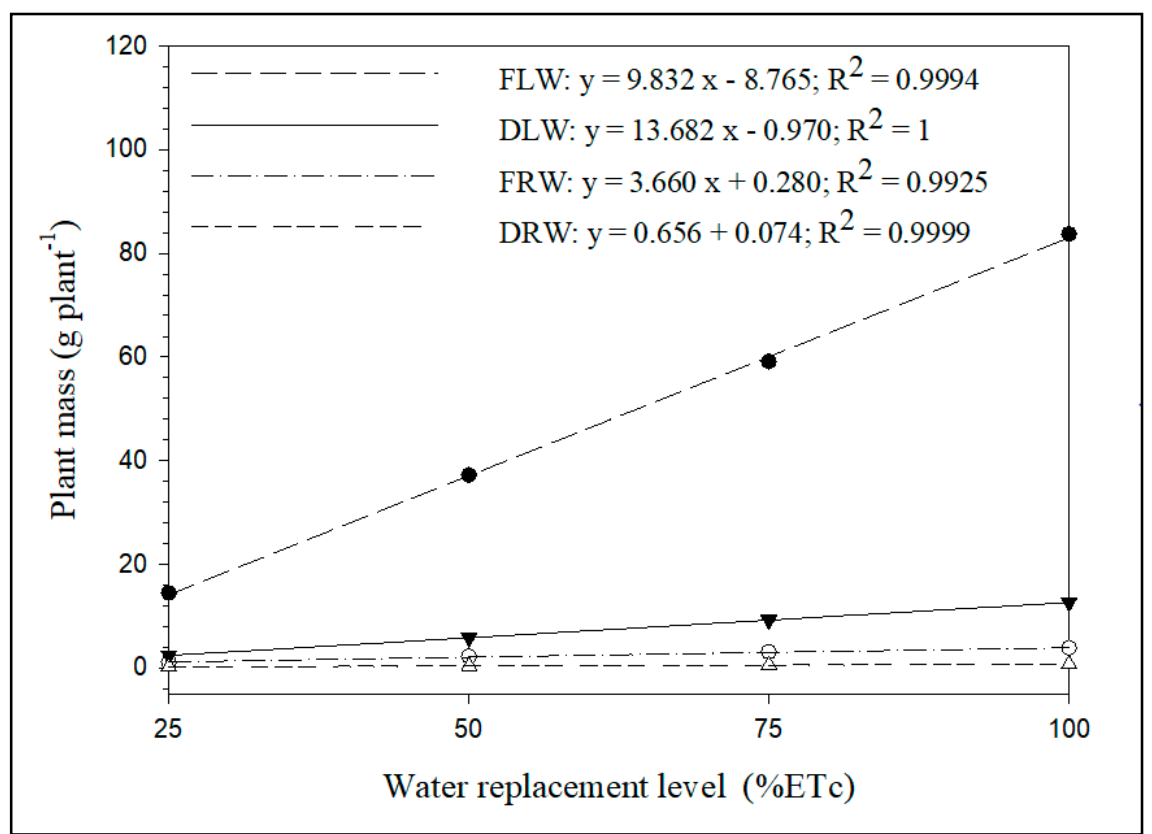

Figure 2. Fresh and dry masses of leaves and roots of basil grown under four water replacement levels. FLW= fresh leaf mass; $\mathrm{DLW}=$ dry leaf mass; FRW= fresh root mass; $\mathrm{DRW}=$ dry root mass. Ceres, IF Goiano, 2018. replacement limited the height of basil plants in all growing environments. The plants grown under shading conditions (50 or $70 \%$ ) were higher in relation to plants grown under full sun (Figure 1).

These responses of plant height can be associated with hormonal changes in plants, as well as to the relationship among phytochromes, cryptochromes and phototropins in plants. Considering that phyB is the dominant phytochorome species in full-sun-grown plants and phyA is the most abundant in plants which grow in shade, possibly, $50 \%$ shading was already enough to alter phyA and phyB in basil and provide higher plants, stimulating etiolation conditions. Plants grown under full sun were kept under high radiation, typical under the conditions where the experiment was carried out. Luminosity reduces stem elongation, which can compromise photosynthesis and, consequently, plant growth.

Growth and development of plants are directly related to growing environment. Generally, plants exposed to greater solar radiation show greater need for water replacement, due to an increase in transpiration and photoassimilate translocation. According to Taiz et al. (2017), water deficit can limit plant growth due to restrictions in division, differentiation and cell stretching. Low water availability causes a reduction in opening of stomata, transpiration, photoassimilate production, nutrient uptake and accumulation of molecules, and changes hormonal balance in tissues.

Vargas (2007) studied basil cultivars Maria Bonita, Mara and Genovese at different water levels, in Sergipe State, and observed partial stomatal closure, decrease in photosynthesis rate and transpiration rate, showing that basil created mechanisms for adaptation to water-deficit stress.

The $70 \%$ shading environment provided less need for water replacement and fewer leaves in relation to other treatments (full sun and 50\% shading).

Basil plants showed positive response to $100 \%$ evapotranspiration replacement in relation to stem diameter. The $70 \%$ shading environment provided smaller stem diameter. 
Plants grown in a $70 \%$ shading environment showed fewer branches in relation to plants grown in 50\% shading and full sun. Luminosity influences on sprouting and inhibition of vegetative bud development in petunia and it is associated with low light intensity (Drummond et al., 2015).

Gelderen et al. (2018) verified that long red wavelength increased auxin signaling in Arabidopsis thaliana shoots, despite not being associated with reduction or increase in auxin signaling in the root. These authors also reported that long red light wavelength reduces auxin signaling in the cortex cells and, consequently, lateral root growth.

Sprout formation still depends on the action of cytokinins, auxin and gibberellin and, probably, shading has altered the balance between auxin and cytokinins, reducing the action of cytokinins. Mutant plants, with low level of cytokinin, showed reduced sprout growth and an increase in root growth. Whereas luminosity favors cytokinins, low luminosity intensity, as well as long days, increased the synthesis of gibberellins, which are associated with auxin. Thus, crop environments directly influence endogenous hormonal balance, providing different morphological responses in plants.

Growing environments influenced leaf fresh mass, root system volume, root length, leaf dry mass and root dry mass (Table 1). Leaf dry and fresh masses of plants grown under full sun and $50 \%$ shading were greater than the ones obtained under $70 \%$ shading.

An increase in water replacement favored the number of branches. Leaf fresh mass, root fresh mass (Figure 2), root system volume, root length, leaf dry mass and root dry mass were influenced by water replacement levels, whereas only the root length was influenced by interaction.

Root growth in response to an increase in water replacement was more significant in shading environments (Figure 3). The water replacement increased the root volume (Figure 4).

Under maximum luminosity conditions $\left(900 \mu \mathrm{mol} \mathrm{m} \mathrm{m}^{-2} \mathrm{~s}^{-1}\right)$, luminosity increased up to $90 \%$ of total light increased biomass of stem and roots, number of branches, and provided

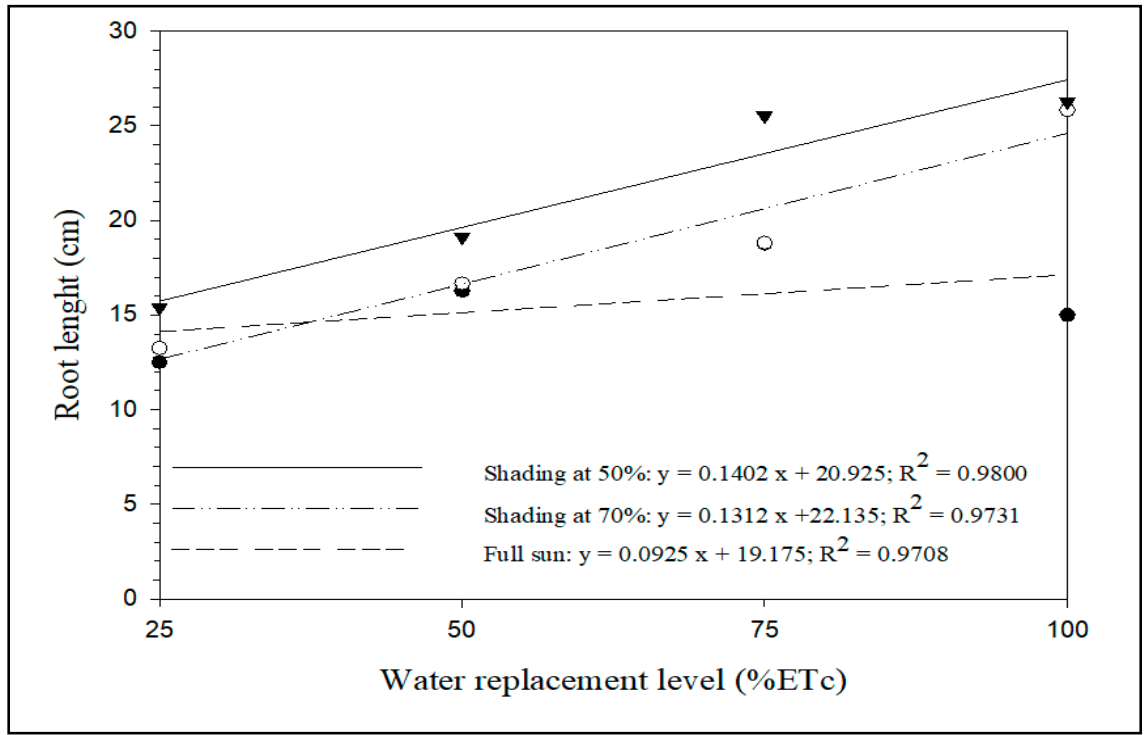

Figure 3. The largest root length of basil grown at three luminosity levels and four water replacement levels. Ceres, IF Goiano, 2018.

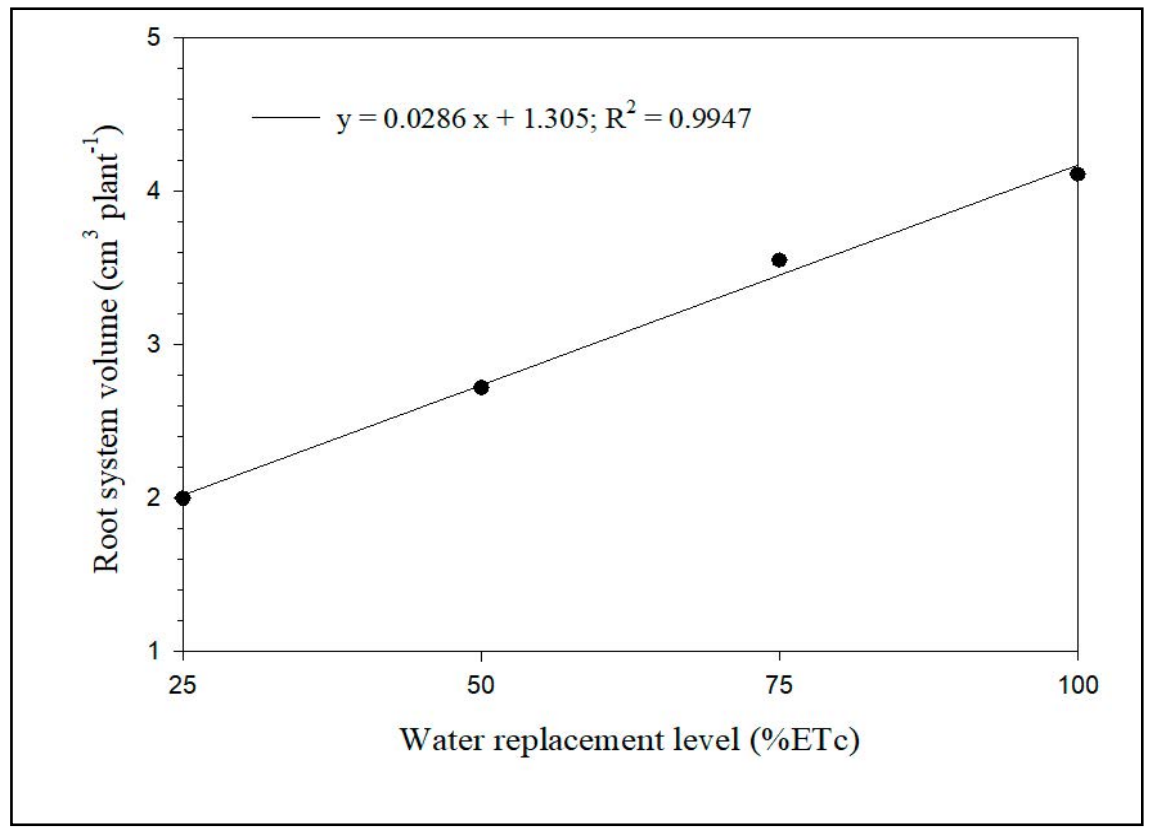

Figure 4. Root system volume per basil plant grown at four water replacement levels. Ceres, IF Goiano, 2018.

higher allocation of biomass in roots in relation to shoot (Scanga, 2011). The highest levels of radiation provided increases in length, volume and fresh and dry root masses of Raphanus sativus (Zha \& Liu, 2018).

Studying Lamium species, under high luminosity, similar results were found by Barisic et al. (2006).

Finally, we noticed that luminosity and water replacement influenced basil growth. The 50 and $70 \%$ solar radiation environments and $100 \%$ water replacement provided an increase in plant height, stem diameter, branch growth, fresh and dry masses of leaves, and number of leaves. However, full sun environment and water replacement increase in $100 \%$ level favored an increase in root dry mass and root volume.

\section{REFERENCES}

ABREU, CB; SANTOS, AR; SOUZA, GS; 
OLIVEIRA, UC; SILVA, JS. 2013. Qualidade de luz no crescimento inicial de plantas de manjericão (Ocimum basilicum L.) em ambiente controlado. Enciclopédia Biosfera, Goiânia: Centro Científico Conhecer, 9: 16. p. 1855 .

ALMEIDA, SMZ; SOARES, AM; CASTRO, EM; VIEIRA, CV; GAJEGO, EB. 2005. Alterações morfológicas e alocação de biomassa em plantas jovens de espécies florestais sob diferentes condições de sombreamento. Ciência Rural 35: 62-68.

BARISIC, N; STOJKOVIC, B; TARASJEV, A. 2006. Plastic responses to light intensity and planting density in three Lamium species. Plant Systematics and Evolution 262: 25-36.

BLANK, AF; CARVALHO FILHO, JLS; SANTOS NETO, AL; ALVES, PB; ARRIGONI-BLANK, MF; SILVA-MANN, R; MENDONÇA, MC. 2004. Caracterização morfológica e agronômica de acessos de manjericão e alfavaca. Horticultura Brasileira 22: $113-116$

CARDOSO, MRD; MARCUZZO, FFN. 2014. Climate classification of Köppen-Geiger for the State of Goiás and the Federal District. Acta Geografica 8: 40-55.
CASAROLI, D; LIER, QJ. 2008. Criteria for determination of vessel capacity. Brazilian Journal of Soil Science 32: 59-66.

DRUMMOND, RS; JANSSEN, BJ; LUO, Z; OPLAAT, C; LEDGER, SE; WOHLERS, MW; SNOWDEN, KC. 2015. Environmental control of branching in petunia. Plant Physiology 168: 735-751.

GELDEREN, K; KANG, C; PAALMAN, R; KEUSKAMP, D; HAYES, S; PIERIK, R. 2018. Far-red light detection in the shoot regulates lateral root development through the HY5 transcription fator. The Plant Cell 30: 101-116.

HAN, YJ; SON, PS; KIM, JI. 2007. Phytochromemediated photomorphogenesis in plants. Journal of Plant Biology 50: 230-240.

MARQUES, PAA; JOSÉ, JV; ROCHA, HS; FRAGA, JREF; SOARES, DA; DUARTE, SN. 2015. Consumo hídrico do manjericão por meio de lisímetro de drenagem. Irriga 20: 745-761.

$\mathrm{OH}, \mathrm{W}$; KIM, KS. 2014. Light intensity and temperature regulate petiole elongation by controlling the content and sensitivity to gibberellin in Cyclamen persicum. Horticulture, Environment and Biotechnology
55: $175-182$

SALOMÃO, LC. 2012. Calibração de tanques evaporimetros de baixo custo sob diferentes diâmetros em ambiente protegido. Botucatu: UNESP. 74p. (Ph.D. Thesis).

SCANGA, SE. 2011. Effects of light intensity and groundwater level on the growth of a globally rare fen plant. Wetlands 31: 773-781.

PEREIRA, RCA; MOREIRA, ALM. 2011. Manjericão: Cultivo e utilização. Fortaleza: Embrapa Agroindústria Tropical. 31p.

TAIZ, L; ZEIGER, E. 2013. Fisiologia Vegetal. 5.ed. Porto Alegre: Artmed. 918p.

TAIZ, L; ZEIGER, E; MOLLER, IM; MURPHY, A. 2017. Fisiologia e Desenvolvimento Vegetal. $6^{\text {a }}$ ed. Porto Alegre: Artmed. 888p.

VARGAS, MEO. 2007. Respostas ecofisiológicas e bioquímicas do Ocimum basilicum L. cultivado em diferentes níveis hídricos. São Cristóvão: UFS. 72p. (M.Sc. Dissertation).

VIEIRA, EL; SOUZA, GS; SANTOS, AR; SANTOS SILVA. J. 2010. Manual de Fisiologia Vegetal. São Luís: EDUFMA. 182p.

ZHA, L; LIU, W. 2018. Effects of light quality, light intensity, and photoperiod on growth and yield of cherry radish grown under red plus blue LEDs. Horticulture, Environment, and Biotechnology 59: 511-518. 